\title{
Strategy Environment Analysis of National Marine Hydrographic Survey

\author{
Xiaoxue $\mathrm{Ma}^{1, \mathrm{a}}$, Yitong $\mathrm{Han}^{1, \mathrm{~b}^{*}}$ and Shina $\mathrm{Jia}^{1, \mathrm{c}}$ \\ ${ }^{1}$ Marine professional college, Dalian maritime university, Dalian 116026, China

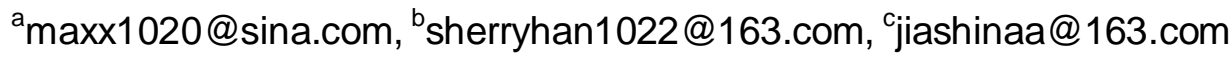 \\ *The corresponding author
}

\begin{abstract}
Keywords: Marine hydrographic survey; SWOT analysis; Development strategy; AHP; Navigation guarantee
\end{abstract}

\begin{abstract}
As an important work to ensure the safety of navigation, marine hydrographic survey is not only the initial and basic link for the construction of integrated navigation system, but also the important content to fulfill the relevant international convention and implement marine management. This paper aims to set up an strategic environmental assessment model of marine hydrographic survey, thus providing a method to evaluate the strategic environment for China's marine hydrographic survey. Based on the tool of SWOT, the strengths, weaknesses, opportunities, and threats of marine hydrographic survey under new era are listed and analyzed totally, and then the index system of marine hydrographic survey development environment model is constructed. The radar figure of marine hydrographic survey strategy index is obtained by the means of designing, handout and recovering questionnaires, and analyzing the questionnaires by AHP. Finally, the thesis finds that at present the marine hydrographic survey is under the condition of good outer development environment and relatively hysteresis inner capacity building.
\end{abstract}

\section{Introduction}

The transformation work of the Maritime system directly under the Ministry of transport of China has ended. Marine hydrographic survey as one of the three core businesses of the three newly formed Navigation Guarantee Center, its future development is facing a new strategic environment, both favorable factors and disadvantages exist. It is not only a good opportunity for development but also obligatory social responsibility for marine hydrographic survey, which plays a basic role in the process of maritime exploiting and utilizing, especially under the national strategy of "marine powers" [1]

\section{Strategic Environmental Assessment Model of Marine Hydrographic Survey}

Establishment of Strategic Environmental Assessment Indicator System. According to the principle of SWOT analysis, the strategic environmental condition of marine hydrographic survey can be divided into four categories: opportunities, threats, advantages and disadvantages. [1,2]Opportunities including: the chances brought by environmental changes of port and shipping (Specifically reflect in four aspects, it is respectively the rapid development of port industry, the needs of traffic safety on waters, national development strategic layout to coastal areas and new requirements of navigation users to the marine hydrographic survey.); The chances brought by the development of science and technology (Specifically embodied in two aspects, namely the development of science and technology in surveying and mapping field and navigation users' demand for new technology[3]; The development chances brought by implementation of the strategy of "marine powers" (It is concretely expressed that, as an important means to safeguard national marine rights and interests, marine hydrographic survey will provide the base for offshore ocean exploitation and provide technical support and services for the abysmal sea resources exploration and development.); The chances brought by the management system reform of marine hydrographic survey (Marine hydrographic survey has been drawn into the first type of public welfare institutions and it will separate government from enterprises, investment, social undertaking 
and market intermediaries, social responsibilities will get reinforced. The establishment of Navigation Guarantee Center is conducive to the integration and reasonable configuration of hydrographic survey resources. According to the requirements of the public institution reform, performance pay has been implemented, it is beneficial to establish an incentive mechanism.)

In the future, the threats that marine hydrographic survey in our country will face are mainly from two aspects, namely the threats of international environment and domestic opponents. On the one hand, western countries have mastered advanced technology and the initiative of equipment standards. International commercial hydrographic service companies enter the Chinese market gradually. In particular, under the situation that all members are competing to participate the affairs of IHO, China is far behind others in terms of soft power as the country has little voice; On the other hand, there is fierce competition in the field of domestic hydrographic service. The phenomenon of personnel float in hydrographic survey is already very serious. About chart sales market, military products occupy a larger proportion and have great competitive strength. At the same time, potential competitors are constantly emerging.

The strengths that marine hydrographic survey face mainly shows in seven aspects[3]: policy support; technological development (including the improvement of the information level of marine management and application, the introduction and absorption of foreign advanced technology and the further enhanced research and development of hydrographic technology); Talents team-building (including emphasis on training and developing the high-tech knowledge-type talents, staff's pride and love of work, the principle that discover able people and put them at suitable posts, provide wide development space for young employees and have the talent incentive mechanism); Internal management system (We have covered the review by the international maritime organization and set up an quality management system which in accordance with international standard. Especially, attach great importance to the innovation of internal management mechanism); Competitive advantage of nautical books (the cycle of chart making is short. What's more, it is not only cover the national coastal port channel, but also has low prices); Construction of chart distribution system (Formed thorough chart distribution system and network) and the advantage of cultural construction.

Finally, the weaknesses is mainly reflected in the following five aspects: a great gap compared with the international advanced hydrographic technology (the national investment on hydrographic technology is relatively insufficient, research and development mechanism remains to be perfect, independent products lack of stability and reliability);Rare reserve of talents (age structure and education composition are unreasonable, knowledge structure system needs to be adjusted, talent introduction mechanism needs correcting and lack of cooperation with colleges and universities); Hydrographic products cannot meet the requirements of safeguarding (compared with developed countries, the type of products are not rich enough; the service channel needs to be further expanded; the customers communication mechanism should be established and perfected; the products have not been formed a unitary system; the service range of nautical books is narrow; lacking of continuous service; the speed of marketization is slow; the site management is not in place and emergency hydrographic ability and speed is not enough); Lack of infrastructure (the national investment is shortage; hydrographic bases shortages and misdistribution; lacking of hydrographic boats and existing boats only have low operations ability); Management function defect(Laws and regulations are imperfect and the technical standard system needs to be perfected.)

Weight Assignment of Index System. Using the AHP, we have determined the weight of each factor in the index system. In order to ensure the objectivity and authenticity of the weight assignment, SWOT questionnaires about hydrographic development strategy were designed firstly and administered to the hydrographic department of Navigation Guarantee Center. According to the statistics, 99 questionnaires have been collected.80 copies were valid, basically met the requirements of the weight assignment of the strategic analysis indicators.

After effective data processing using AHP, listed related factors of marine hydrographic strategy analysis----strength factors $(\mathrm{S})$, weaknesses factors $(\mathrm{W})$, opportunity factors $(\mathrm{O})$ and threat 
factors (T), and obtained of absolute or relative weights of the indexes at all levels, finally got the total weighted score of all strategic factors. Specific values are shown in Table 1.

Table 1 The gross weight value of strategy factors

\begin{tabular}{|l|l|l|l|l|}
\hline $\begin{array}{l}\text { strategic } \\
\text { factors }\end{array}$ & $\begin{array}{l}\text { strength } \\
\text { factors }\end{array}$ & $\begin{array}{l}\text { weaknesses } \\
\text { factors }\end{array}$ & $\begin{array}{l}\text { opportunity } \\
\text { factors }\end{array}$ & $\begin{array}{l}\text { threat } \\
\text { factors }\end{array}$ \\
\hline weight value & 2.802 & -2.864 & 2.847 & -2.716 \\
\hline
\end{tabular}

\section{Results Analysis}

Strategy Index Analysis of Marine Hydrographic Survey Based on Radar Chart. The development strategy indexes of marine hydrographic survey in our country are described in Fig 1. The radar charts are comprised of four concentric circles, each circle represents a score level [4], the smallest one represents the minimum score level is 1 points and the biggest one represents the maximum score level is 4 points. Each node represents a specific point of a certain index. Through the radar charts, we can clearly see the present situation and level of four factors, which provide a strong basis of problems finding and making improvement for marine hydrographic department.
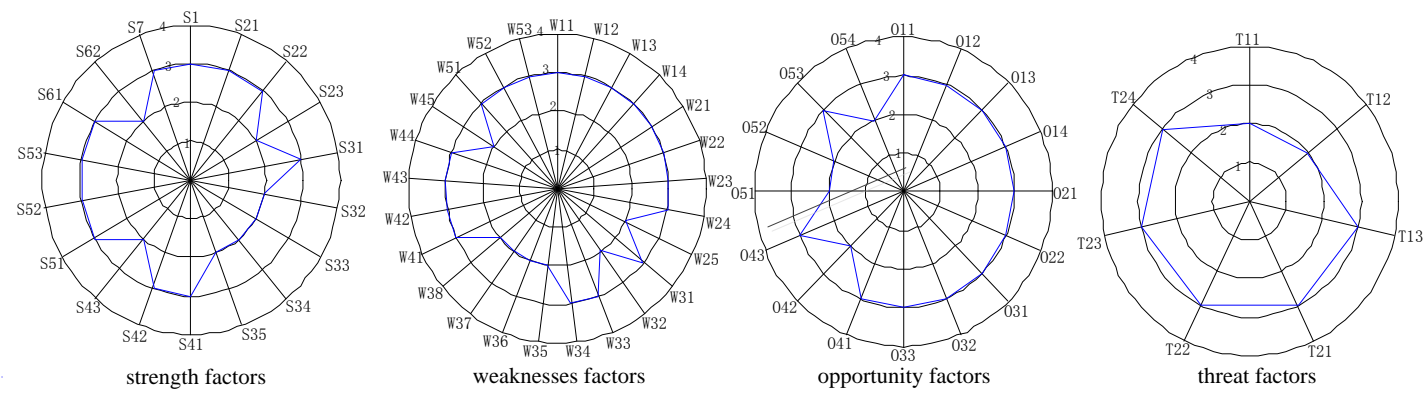

Figure 1. the radar figure of factors of SWOT analysis

Comprehensive Analysis of Marine Hydrographic Survey Based on SWOT. According to the detailed analysis of external and internal factors of the strategic development environment, to China's marine hydrographic survey, the total score of development strengths is 2.802 (as shown in Fig. 2, node S), the weaknesses is -2.864 (as shown in Fig. 2, node W); the opportunities is 2.847 (as shown in Fig. 2, node O), the threats is -2.716 (as shown in Fig. 2, node T). The total weighted score of the internal development capacity (the sum of strength and weakness) is -0.062 , and the total weighted score of the external development environment (the sum of opportunity and threat) is 0.131 . 


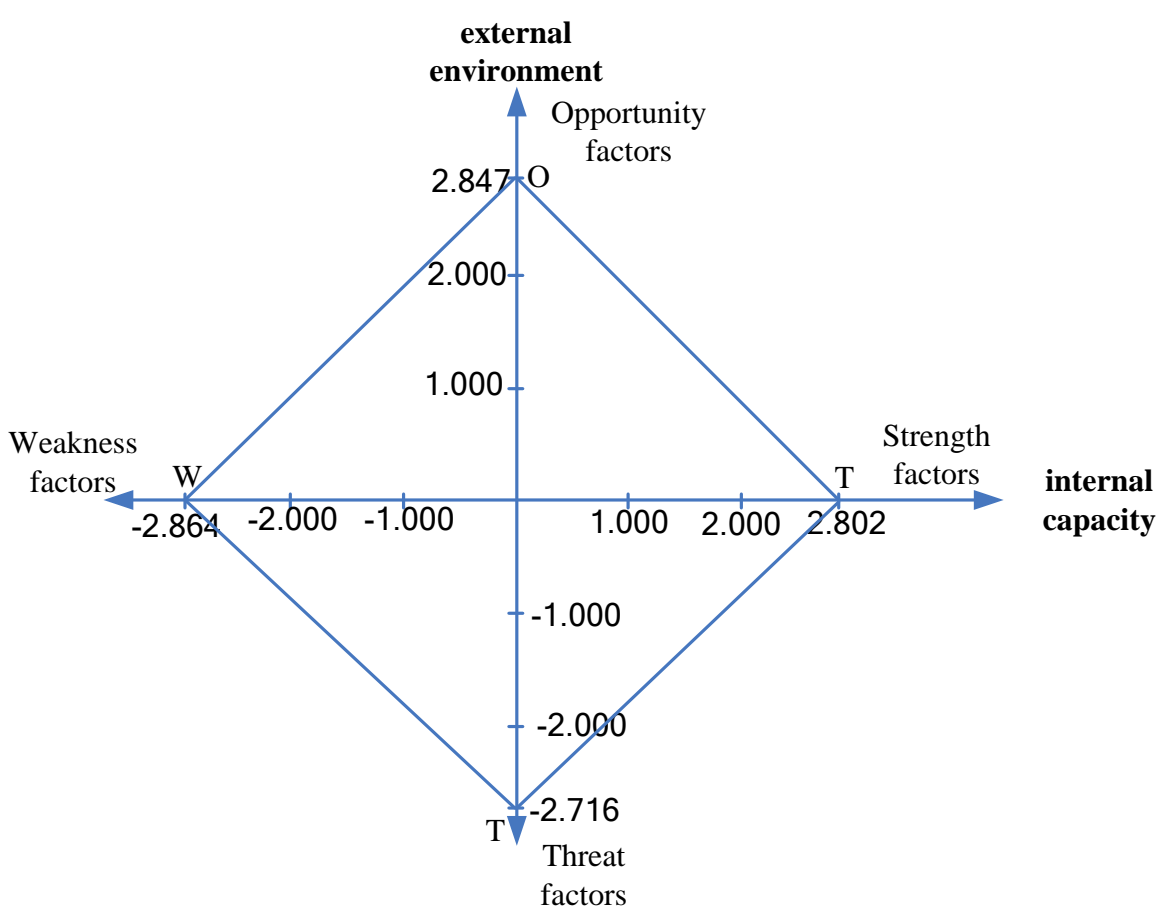

Figure 2. Integrated figure of marine hydrographic survey SWOT analysis

Based on the above score result, we can draw the conclusion that the coordinates of comprehensive evaluation point for marine hydrographic strategy environment is $(-0.062,0.131)$. The coordinate is located in the second quadrant of SWOT comprehensive analysis chart, which shows China's marine hydrographic industry is in an relatively good external environment currently, but the construction of internal capacity is lagging. Among them, the development opportunities are greater than the threats. However, we also lack of internal development strengths, still have many problems and difficulties will be faced [5].

In addition, according to the analysis about the development trend of China's marine hydrographic survey based on SWOT analysis, we can find the trend is not optimistic. The largest area of the quadrangle that surrounded by the SOWT is located in the second quadrant, maritime will develop with shrinking type unless appropriate measures are taken against it. The ideal development trend is that the largest area is located in the first quadrant, and the worst is in the third quadrant [6].

\section{Conclusions}

Although the development trend of China's marine hydrographic industry is not optimistic, it doesn't mean nothing can hydrographic department do. On the contrary, it shows that we are in a period that has bright prospects [7]. Because comparing with external environment factors, internal capabilities are easier to improve through their own efforts. Therefore, in the period ahead, China's marine hydrographic industry will be in a strategic development environment which opportunities and challenges exist side by side. If we can manage the transition through own transformation and development (to eliminate the disadvantage factors, consolidate the advantages of factors), China's marine hydrographic industry will open up a new field for development and usher in the great-leap-forward development. 


\section{References}

[1] Y. Cao: China Shipping, Vol. 9 (2009) No.7, p.24(In Chinese)

[2] B. Hu: Pacific Journal, Vol. 22 (2014) No.3, p.10(In Chinese)

[3] X. Tang: Logistics Technology, (2016) No.2, p.89(In Chinese)

[4] L. Qin: Port Economy, (2016) No.5, p.26(In Chinese)

[5] Hydrographic Development Strategy Research Project Group: The Research Report on the development strategy of Hydrographic in China (China Surveying and Mapping Publishing House, China 2005).(In Chinese)

[6] T.Y. Bai: China Maritime, (2014) No.10, p.22(In Chinese)

[7] H.Y. Li, X,Li and J.C.Song: Coal Journal, Vol. 37 (2012) No.11, p.17(In Chinese)

[8] G.J. Liu: The Research of Strategy for Surveying and Mapping Institutions (MS., Xi'an University of Electronic Science and Technology, China 2009), p.15(In Chinese)

[9] X.G. Wang: Strategic Performance Management (China Economic Publishing House, China 2011)(In Chinese)

[10] Information on http://www.cehui8.com/(In Chinese) 